\title{
MONITORING KETINGGIAN PLATEAU BERBASIS MIKROKONTROLER MENGGUNAKAN ATMEGA 328 DAN SENSOR ALTIMETER
}

\author{
Eko Budihartono') dan Ida Afriliana ${ }^{2)}$ \\ ${ }^{1,2}$ Program Studi DIII Teknik Komputer, Politeknik Harapan Bersama Tegal \\ 1,2 Program Mataram No. 9 Tegal \\ Email: tara.niscita@gmail.com ${ }^{1)}$, idaafriliana@yahoo.co.id ${ }^{2)}$
}

\begin{abstract}
ABSTRAK]
Pengertian dataran tinggi yaitu dataran luas yang letaknya di daerah tinggi atau pegunungan disebut dengan dataran tinggi, dinamakan juga plato (plateau). Pengukuran tinggi tempat biasanya didasarkan pada perbandingan tekanan udara tempat tersebut dengan permukaan laut sehingga nilainya dinyatakan dalam satuan meter diatas permukaan laut. Perangkat sensor altimeter merupakan salah satu sensor yang digunakan untuk mengukur ketinggian dataran rendah (laut) hingga ke dataran tinggi (bukit), Aplikasi sensor altimeter sebenarnya sudah ada di smartphone atau android namun aplikasi ini bergantung pada koneksi internet sebagai penyedia layanan dan jika berada di dataran tinggi koneksi akan hilang seketika karena koneksi internet tidak terjangkau di atas ketinggian lebih dari $1000 \mathrm{Mdpl}$. Penelitian ini menggunakan alat sensor Altimeter sebagai pengendali sensor ketinggian. Altimeter merupakan sensor untuk mengukur ketinggian suatu titik dari permukaan laut. Prinsip kerja dari sensor altimeter menggunakan tekanan udara, yaitu dengan bertambahnya suatu ketinggian, maka tekanan udara akan berkurang. Adanya sensor Altimeter dengan berbasis ATMega328 ini semua orang dapat mengukur ketinggian di dataran tinggi tanpa ada kendala jaringan karena ATMega328 dirancang secara khusus tanpa mengandalkan bantuan jaringan atau internet, Alat ini dirancang khusus menggunakan sensor Altimeter agar lebih praktis untuk mengukur dataran tinggi dari titik nol laut sampai ke dataran tinggi menggunakan sensor altimeter dan aplikasi platium C Arduino IDE dengan cara kerja otomatis. Alat ini hanya membutuhkan baterai atau power bank untuk menampilkan di layar LCD. Pembuatan alat ini dapat menjadi salah satu solusi yang dapat digunakan untuk mempermudah proses pengukuran ketinggian dan suhu di dataran tinggi.
\end{abstract}

Kata Kunci: Arduino IDE, ATMega 328, LCD, Sensor Altimeter, Arduino Software (IDE)

\section{PENDAHULUAN}

Pengertian dataran tinggi yaitu dataran luas yang letaknya di daerah tinggi atau pegunungan disebut dengan dataran tinggi, dinamakan juga plato (plateau). Dengan berubahnya ketinggian tempat, maka kondisi lingkungan pun akan jelas terlihat. Analisir lingkungan yang perubahannya tampak jelas bila dikaitkan dengan ketinggian yaitu suhu dan kandungan oksigen $(\mathrm{O} 2)$ dalam udara. Semakin bertambah ketinggian maka suhu akan turun dan kandungan oksigen dalam udara akan menipis. Fenomena alam seperti ini teramat penting untuk diketahui sehingga dapat dengan mudah mempelajari proses fisiologi tubuh di daerah ketinggian.(Restanti, 2012)

Hiking atau Mendaki gunung merupakan salah satu kegiatan alam terbuka yang banyak diminati banyak orang. Aktivitas mendaki gunung tidak lagi menjadi kegiatan yang eksklusif bagi kalangan orang - orang tertentu atau bias disebut pecinta alam dan sejenisnya, akan tetapi mendaki gunung menjadi pilihan orang - orang di kalangan umum untuk melatih fisik dan mental mereka.(Meivita, 2016)

Kemajuan teknologi sangat membantu dalam bidang informasi, seperti halnya sensor altimeter yang kini banyak digunakan untuk mendapatkan informasi yang diinginkan tanpa keterbatasan ruang dan waktu dengan secara maksimal cara kerja sistem sensor tersebut. Terutama hal-hal yang dapat membantu pekerjaan manusia sehingga menjadi lebih mudah dan efisien, perangkat sensor altimeter merupakan salah satu sensor yang digunakan untuk mengukur ketinggian dataran rendah (laut) hingga ke dataran tinggi (bukit) tanpa membuang waktu yang begitu lama dan mengurangi informasi yang terdapat padanya. Seiring perkembangan teknologi sensor altimeter saat ini, kajian mengenai tinggi dasar laut tidak hanya dilakukan untuk perairan lepas pantai, tetapi teknologi sensor altimeter ini juga dapat digunakan untuk mengukur dataran tinggi. Aplikasi sensor altimeter sebenarnya sudah ada di smartphone atau android namun aplikasi ini bergantung pada koneksi internet sebagai penyedia layanan. Kekurangan dari 
aplikasi ini adalah ketika koneksi internet tidak ditemukan atau tidak terdapat jaringan, aplikasi akan berhenti dan tidak berfungsi. Dan jika berada di dataran tinggi koneksi akan hilang seketika karena koneksi internet tidak terjangkau di atas ketinggian lebih dari $1000 \mathrm{Mdpl}$.

Masalah spesifik yang terjadi pada penelitian sebelumya yaitu, program interface yang digunakan terdiri dari program untuk deteksi sensor, program untuk pengolahan sinyal dan program untuk menghasilkan informasi yang ditampilkan pada LCD dan LED dengan menggunakan mikrokontroller ATMega 8535, pemrograman menggunakan CVAVR, sedangkan perangkat lunak pemrograman dan donloader menggunakan CodeVisionAVR Versi 2.03.9.(Zuly Budiarso, 2011). Alat monitoring ketinggian air pada bendungan dari jarak jauh menggunakan sistem android via jaringan wi-fi. Dimana Sensor konduktifitas mendeteksi ketinggian air pada bendungan dan dapat dimonitoring bendungan tersebut dari jarak jauh dengan menggunakan sistem android via jaringan wi-fi, bahwa mikrokontroler AT89S51 sebagai pengontrol dapat dikendalikan dengan menggunakan program Codevision AVR yang juga dihubungkan pada PC sehingga dapat ditampilkan visualisasi bendungan dengan program Visual basic 6.0 dan dimonitoring dari jarak jauh menggunakan sistem android Via jaringan wi-fi. (Girsang and Perangin-angin, 2012), Sistem monitoring dan peringatan yang menggunakan web dan sms gateway. Sistem monitoring ketinggian air dibuat agar dapat mudah diakses kapan saja dan dimana saja. Sistem peringatan juga dibuat agar dapat menyampaikan peringatan dengan cepat, dan memiliki wilayah cakupan yang luas. Dengan menggunakan sistem ini dapat dipantau ketinggian air secara real time melalui halaman web, dan mendapatkan peringatan akan terjadinya banjir melalui pesan singkat. Sehingga sistem ini dapat membantu pengguna, terhindar ataupun dapat menekan kerugian yang ditimbulkan dari banjir yang terjadi.(Alfred Tenggono, Yovan Wijaya Kusuma, 2015). Rancangan alat untuk mengawasi ketinggian air pada bendungan yang terhubung dengan sungai bengawan solo menggunakan sensor ultrasonik yang di proses dengan menggunakan mikokontroler dan jaringan wifi sebagai sarana koneksi internet serta media monitoring antarmuka melalui smartphone maupun laptop. Yang nantinya akan secara terus menerus memberikan informasi dan peringatan pada operator jika tingkat ketinggian air mencapai batas normal melalui peringatan dari sms gateway, Sehingga dengan adanya alat yang dirancang dalam penelitian ini ketinggian air dapat di ketahui secara otomatis. Alat ini dapat di jadikan sebagai peringatan dini potensi bahaya banjir di daerah sungai bengawan solo di kota lamongan. Dengan kata lain akan terjadi efektifitas pada penerapan teknologi tepat guna.(Amelius Andi Mansawan, 2017)

Pengetahuan sifat-sifat Altimeter dan ATMega328 sangat diperlukan untuk mengetahui pengukur ketinggian secara mudah. Hal ini disebabkan karena pengukuran sebelumnya harus menggunakan akses internet. Alat yang dibuat ini dirancang khusus tanpa menggunakan sinyal ataupun kuota, harganya murah dan mudah untuk dibuat. Hal ini mengingat di dataran tinggi jarang sekali adanya jaringan (sinyal), karena bekerja dengan baterai bukan dengan jaringan sehingga mudah untuk digunakan untuk kalangan pendaki atau umum. [2]

Penelitian ini menggunakan alat sensor Altimeter sebagai pengendali sensor ketinggian. Altimeter merupakan sensor untuk mengukur ketinggian suatu titik dari permukaan laut, umumnya alat tersebut digunakan untuk proses navigasi pada penerbangan dan untuk pendakian gunung. Prinsip kerja dari sensor altimeter menggunakan tekanan udara, yaitu dengan bertambahnya suatu ketinggian, maka tekanan udara akan berkurang.

Adanya sensor Altimeter dengan berbasis ATMega328 ini semua orang dapat mengukur ketinggian di dataran tinggi tanpa ada kendala jaringan karena ATMega328 dirancang secara khusus tanpa mengandalkan bantuan jaringan atau internet, contoh di bukit yang memiliki ketinggian tanpa adanya jaringan atau paket data (internet) bisa digunakan. Alat ini dirancang khusus menggunakan sensor Altimeter agar lebih praktis untuk mengukur dataran tinggi dari titik nol laut sampai ke dataran tinggi menggunakan sensor altimeter dan aplikasi platium C Arduino IDE dengan cara kerja otomatis sehingga tidak terlalu mengeluarkan biaya untuk membeli alat dengan harga yang relatif mahal. Alat ini hanya membutuhkan baterai atau power bank untuk menampilkan di layar LCD. Pembuatan alat ini dapat menjadi salah satu solusi yang dapat digunakan untuk mempermudah proses pengukuran di dataran tinggi. Dari prinsip tersebut maka, dirancang sebuah alat sensor untuk mengukur ketinggian berdasarkan tekanan udara tertentu untuk mengetahui kondisi tekanan udara di lingkungan sekitar yang dipijak sekarang.

\section{RUANG LINGKUP}

Dalam penelitian ini permasalahan mencakup:

1. Cakupan permasalahan Adapun cakupan permasalan dalam penelitian ini adalah membuat alat monitoring ketinggian plateau berbasis arduino menggunakan mikrokontroler Atmega 328 dan Sensor Altimeter. 
2. Batasan-batasan penelitian

Batasan-batasan dalam penelitian ini adalah:

Perangkat-perangkat yang digunakan dalam mengukur ketinggian Plateau antara lain Arduino Uno, Atmega 328, LCD 6x2, Sensor Altimeter, Arduino Software (IDE)

3. Rencana hasil yang didapatkan

Hasil yang didapatkan alat pengukur ketinggian untuk mempermudah proses pengukuran tanpa adanya jaringan atau paket data (internet), sehingga di harapkan dapat membantu pendaki atau pengguna dalam mengukur ketinggian dataran tinggi (PLATEAU).

\section{BAHAN DAN METODE}

Persiapan alat-alat yang akan digunakan dalam membuat alat monitoring ketinggian plateau berbasis arduiino menggunakan mikrokontroler Atmega 328 dan Sensor Altimeter sebagai alat pengukur ketinggian untuk mempermudah proses pengukuran tanpa adanya jaringan atau paket data (internet) sebagai berikut :

\subsection{Arduino Uno ( IDE )}

Arduino adalah pengendali mikro single-board yang bersifat open sourch, diturunkan dari wiring platfrom, dirancang untuk memudahkan pengguna elektronik dalam berbagai bidang. Hardware memiliki prosesor Atmel AVR dan software memiliki bahasa pemrograman sendiri, sedangkan board sendiri pada Arduino Software berdampak pada dua parameter yaitu kecepatan CPU dan baudrate yang digunakan ketika melakukan kompilisasi dan meng-upload sketch. Fungsi Arduino disini sebagai pelengkap ATMega 328 untuk kompilisasi dan mengupload koding atau bahasa pemrograman yang sudah ada.(Djuandi, 2011) Bentuk dari Arduino uno dapat dilihat pada gambar 1 .

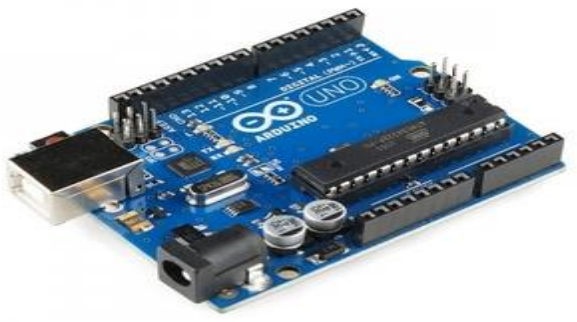

\section{Gambar 1. Arduino Uno (IDE)}

\subsection{Atmega 328}

ATMega merupakan mikrokontroler keluarga AVR 8 bit. ATMega 16, ATMega 32, ATMega328, atmega mempunyai memory $1 \mathrm{~KB}$ sebagai tempat penyimpanan data semi permanent karena EEPROM tetap daya penyimpanan data meskipun catu daya dimatikan, memiliki pin I/O digital sebanyak 14 pin yang membedakan antara mikrokontroler antara lain adalah, ukuran memori.(M. Syafik Mukhlis, Yamato, 2015) Bentuk dari Atmega dapat dilihat pada gambar 2.

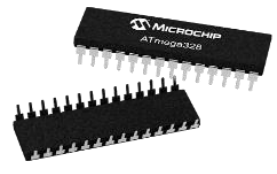

\subsection{LCD 16x2}

Gambar 2. Atmega 328

LCD Display 1602 berfungsi untuk menampilkan karakter angka, huruf ataupun symbol dengan lebih baik dan dengan konsumsi arus yang rendah. Pemrogramanya sama denga lcd yang lain memiliki 14 pin(1-13) atau 16 pin (0 sampai 15). Delapan (8) dari mereka semua adalah data pin yang mengambil data dari unit eksternal dan menampilkannya di layar. Cara alat ini bekerja adalah dengan cara menggabungkan komponen-komponen yang lain sehingga hasil bias dilihat di layar lcd menghubungkan lcd ini tanpa digunakanya sinyal ataupun Wifi. Berikut contoh bentuk dari Lcd (M. Syafik Mukhlis, Yamato, 2015) Display 1602 Shield dapat dilihat pada gambar 3 .

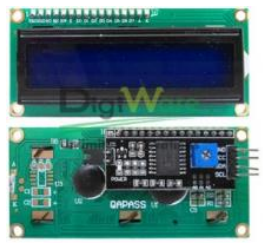

\section{Gambar 3. LCD Display 1602}

\subsection{Sensor Altimeter}

Alat sensor altimeter yaitu untuk mengukur ketinggian suatu titik dari permukaan laut. Biasanya alat ini digunakan untuk keperluan dalam penerbangan, pendakian, dan kegiatan yang berhubungan dengan ketinggian. Alat ini bersifat barometrik. Pengukuran tinggi tempat didasarkan pada tekanan udara tempat tersebut dibandingkan dengan tempat lainnya. Pengukuran tinggi tempat biasanya didasarkan pada perbandingan tekanan udara tempat tersebut dengan permukaan laut sehingga nilainya dinyatakan dalam satuan meter diatas permukaan laut.(Hadinegara, 2018) Contoh bentuk dari Sensor Altimeter dapat dilihat pada gambar 4.

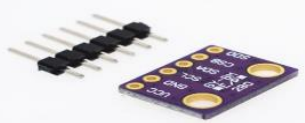

\section{Gambar 4. Sensor Altimeter Bmp280}

\subsection{Arduino Software (IDE)}

Pemrograman Arduino melalui software Arduino Software IDE, Arduino menggunakan bahasa pemrograman sendiri yang menyerupai Bahasa $\mathrm{C}(\mathrm{C}++)$. Bahasa pemrograman Arduino (Sketch) sudah dilakukan perubahan untuk memudahkan pemula dalam melakukan pemrograman dari bahasa aslinya.

Arduino berfungsi untuk melakukan checking kode atau coding yang dibuat apakah sudah sesuai dengan 
kaidah pemrograman yang ada atau belum. Arduino IDE dibuat dari bahasa pemrograman JAVA. Arduino IDE juga dilengkapi dengan library $\mathrm{C} / \mathrm{C}++$ yang biasa disebut Wiring yang membuat operasi input dan output menjadi lebih mudah. Arduino IDE ini dikembangkan dari software Processing yang dirombak menjadi Arduino IDE khusus untuk pemrograman dengan Arduino.

Program yang ditulis dengan menggunaan Arduino Software (IDE) disebut sebagai sketch. Sketch ditulis dalam suatu editor teks dan disimpan dalam file dengan ekstensi.ino.Teks editor pada Arduino Software memiliki fitur seperti cutting/paste dan seraching/replacing sehingga memudahkan kamu dalam menulis kode program.

Pada Software Arduino IDE, terdapat semacam message box berwarna hitam yang berfungsi menampilkan status, seperti pesan error,compile, dan upload program. Di bagian bawah paling kanan Sotware Arduino IDE, menunjukan board yang terkonfigurasi beserta COM Ports yang digunakan. Berikut contoh bentuk dari Arduino IDE dapat di lihatpada gambar 5.

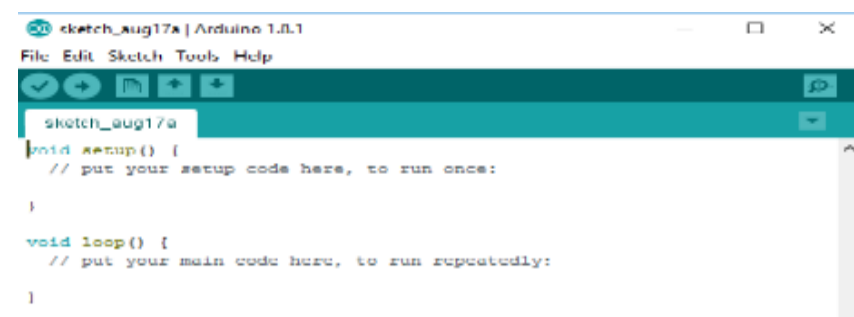

Gambar 5. Tampilan Arduino IDE

Dalam rencana penelitian ini menggunakan metode SDLC (System Development Life Cycle) dengan tahapan sebagai berikut.(Dari, 2015). Tahapan Metode SDLC (System Development Life Cycle) yaitu:

\section{Planning (Perencanaan)}

Tahap ini adalah tahap penentuan hal-hal penting sebagai dasar dari permasalahan yang akan dianalisis. Dalam tahap ini dilakukan identifikasi masalah, pengumpulan data berupa studi literatur, wawancara dan observasi, menentukan kebutuhan sistem, mengevaluasi berbagai solusi alternatif dan melakukan verifikasi data. Observasi ini berkembang seiring meningkatnya keperluan manusia akan suatu system yang dapat bekerja secara otomatis dan handal. Salah satunya adalah pengukur ketinggian plateau dengan sensor Altimeter. Saat ini akan direncanakan uji coba pengembangan pengukuran ketinggian yang merupakan salah satu kebutuhan bagi para pendaki. Penelitian ini bertujuan untuk mendesain dan menghasilkan sebuah sensor altimeter ketinggian sederhana yang sesuai untuk para pendaki dan masyarakat umum. Serta menghasilkan pengukuran yang akurat.

\section{Analysis (analisis)}

Pada tahap ini ditentukan model data yang akan digunakan dan model proses yang akan diterapkan. Pada tahap ini juga nantinya akan ditelaah lebih lanjut. Semua data-data pengamatan yang sebelumnya telah dibuat kemudian di rekapitulasi. Data-data yang sudah terkumpul melalui sensor Altimeter bisa didokumentasikan lewat foto, pengamatan secara langsung, dan informasi yang diketahui kemudian diklasifikasikan dan dianalisis secara deskriptif.

\section{Design (Desain)}

Tahap ini merupakan suatu proses menginventarisir dan mengubah kebutuhan-kebutuhan menjadi bentuk karakteristik yang dimengerti oleh perangkat lunak sebelum pembuatan alat.. gambaran sekaligus rancangan yang menjadi dasar suatu alat atau benda yang biasanya dirancang di atas kertas terlebih dahulu, desain juga merupakan bentuk rumusan dari suatu proses pemikiran, mencakup Hardware dan Software. Penelitian ini bertujuan untuk mendesain dan menghasilkan sebuah sensor altimeter ketinggian sederhana yang sesuai untuk para pendaki atau pengguna. Serta menghasilkan pengukuran yang akurat.

\section{Implementation (Implementasi)}

Pada tahap implementasi kegiatan yang dilakukan adalah dengan menulis pengetahuan yang telah direpresentasikan (disandikan) dengan bahasa pemrograman, instalasi, demonstrasi dan penerapan sistem, orientasi pemakai, keamanan, dokumentasi dan integrasi. Sebuah instruksi untuk menjalankan suatu bahasa pemrograman komputer agar melakukan langkahlangkah tertentu dalam menyelesaikan masalah dalam rangkaian. Dari sebuah sensor Altimeter sehingga menjadi suatu rancangan yang berbentuk alat untuk mengukur sebuah ketinggian di dataran tinggi.

\section{Testing (Uji Coba)}

Setelah tahapan implementasi selesai dikerjakan, tahap selanjutnya adalah dengan melakukan pengujian hasil implementasi. Program juga harus diuji coba dimana difokuskan terhadap tiga aktivitas yakni logika internal perangkat lunak, pemastian bahwa semua perintah yang ada telah dicoba dan fungsi eksternal untuk memastikan bahwa dengan masukan tertentu suatu fungsi akan menghasilkan keluaran sesuai yang dikehendaki, yaitu dengan melakukan pengujian terhadap alat pengukur plateu.

\section{Maintenance (Pemeliharaan)}

Tahapan terakhir dalam sistem ini adalah melakukan pemeliharaan, diantaranya yaitu dengan memperbaiki desain dan error program dan menjaga sistem dari kemungkinan masalah di masa yang akan datang. 


\subsection{Perancangan Sistem}

Perancangan sistem ini dapat diketahui hubungan antara komponen - komponen pendukung dari sistem yang akan dirancang. Sistem yang digambar dalam bentuk Blok Diagram dan Flowchart.

\section{Blok Diagram}

Perancangan blok diagram dalam pembuatan alat ini dibuat menjadi 4 bagian blok diagram. Blok Diagram dapat dilihat pada Gambar 7.

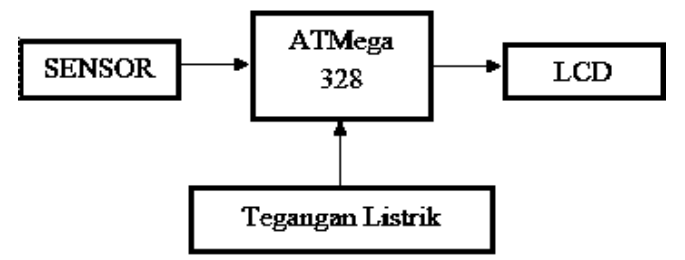

\section{Gambar 6. Perancangan Diagram Blok}

Fungsi dari tiap blok dalam gambar tersebut adalah sebagai berikut:

\section{1) ATMega}

ATMega yang digunakan adalah ATMega 328, atmega pada system ini digunakan sebagai input ataupun outputan sensor maupun LCD yang disambungkan melalui pin pada atmega.

\section{2) Sensor}

Sebuah alat untuk mengukur ketinggian suatu titik dari permukaan laut (daratan rendah ke dataran tinggi). Biasanya alat ini digunakan untuk keperluan dalam penerbangan, pendakian, dan kegiatan yang berhubungan dengan ketinggian.

3) LCD (Liquid Cristal Display)

Yang digunakan adalah modul LCD 16x2, LCD dalam hal ini berfungsi untuk menampilkan data dalam bentuk karakter, huruf, angka ataupun grafik.

4) Tegangan Arus Listrik

Power supply berfungsi untuk mengaliri arus listrik untuk komponen-komponen hardware pada komputer dengan arus searah, arus listrik yang masuk kedalam tegangan listrik berupa arus bolak-balik kemudian dikonverter (dirubah) menjadi arus searah baru kemudian disupply kedalam komponen-komponen elektronika.
2. Diagram Alur (Flowchart)

Diagram Alur Alat Pengukur Ketinggian dapat dilihat pada Gambar 8.

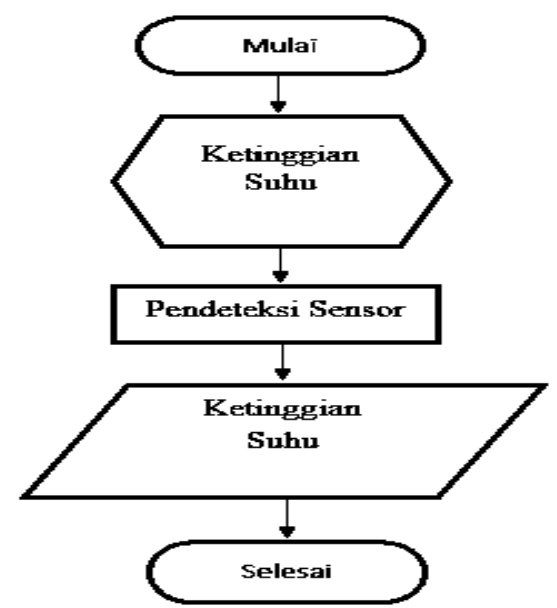

Gambar 7. Diagram Alur (Flowchart)

Keterangan Flowchart Alat Pengukur Ketinggian :

1) Mulai : Proses Persiapan.

2) Data Sensor :Pengumpulan data sensor yang akan digunakan.

3) Pendeteksian Sensor : Dimana Sensor yang digunakan akan bekerja sesuai dengan apa yang ditentukan.

4) ketinggian : selanjutnya jika mengukur ketinggian berhasil maka akan terhubung ke ATMega 328 dan muncul di layar LCD dengan posisi ketinggian yang dipijak saat ini.

5). Selesai : proses yang dihasilkan sudah menghasilkan output.

Instalasi perangkat keras merupakan suatu proses instalasi alat ataupun perakitan alat yang digunakan dalam membangun adalah Sensor Altimeter untuk mengukur ketinggian dari dataran titik 0 laut sampai ke dataran tinggi berbasis Atmega 328. Sensor untuk mengukur tekanan udara (Barometer) dengan nilai output berupa satuan $\mathrm{Pa}$ (pascal). Dengan memanfaatkan tekanan udara berdasar ketinggian terhadap permukaan laut, maka sensor ini juga dapat mengukur ketinggian (Altimeter). Rumus Tekanan Udara (Barometer) dapat di lihat pada Tabel 1.

$$
\begin{aligned}
p & =p_{0} \cdot\left(1-\frac{L \cdot h}{T_{0}}\right)^{\frac{g \mu}{N_{0} L}} \\
& =p_{0} \cdot\left(1-\frac{g \cdot h}{c_{p} \cdot T_{0}}\right)^{\frac{p^{*} x}{\kappa_{0}}} \approx p_{0} \cdot \exp \left(-\frac{g \cdot h \cdot M}{T_{0} \cdot R_{0}}\right)
\end{aligned}
$$


Tabel 1. Rumus Tekanan Udara (Barometer)

\begin{tabular}{|c|l|c|}
\hline Parameter & \multicolumn{1}{|c|}{ Description } & Value \\
\hline$p_{0}$ & $\begin{array}{l}\text { Sea level standard } \\
\text { atmospheric pressure }\end{array}$ & $101325 \mathrm{~Pa}$ \\
\hline$L$ & $\begin{array}{l}\text { Temperature lapse } \\
\text { rate, }=\mathrm{g} / \mathrm{c}_{\mathrm{p}} \text { for dry air }\end{array}$ & $\sim 0.00976 \mathrm{~K} / \mathrm{m}$ \\
\hline$c_{\mathrm{p}}$ & $\begin{array}{l}\text { Constant-pressure } \\
\text { specific heat }\end{array}$ & $1004.68506 \mathrm{~J} / \mathrm{kg} \cdot \mathrm{K})$ \\
\hline$T_{0}$ & $\begin{array}{l}\text { Sea level standard } \\
\text { temperature }\end{array}$ & $288.16 \mathrm{~K}$ \\
\hline$g$ & $\begin{array}{l}\text { Earth-surface } \\
\text { gravitational } \\
\text { acceleration }\end{array}$ & $0.80665 \mathrm{~m} / \mathrm{s}^{2}$ \\
\hline$M^{2}$ & Molar mass of dry air & $0.02896968 \mathrm{~kg} / \mathrm{mol}$ \\
\hline$R_{0}$ & Universal gas constant & $8.314462618 \mathrm{~J} /(\mathrm{mol} \cdot \mathrm{K})$ \\
\hline
\end{tabular}

maka, untuk mendapatkan hasil ketinggian kita harus memasukkan nilai tekanan udara yang didapat dari sensor ini. Namun tak perlu khawatir karena arduino telah membuat library untuk sensor ini sehingga untuk mendapatkan nilai ketinggian lebih mudah.

\section{PEMBAHASAN}

Pembuatan alat pengukur ketinggian dataran tinggi (PLATEAU) ini terdiri dari perancangan software dan perancangan hardware. Perancangan software ini menggunakan Sofware Arduino Uno yang dapat dijalankan pada sistem operasi berbasis Atmega 328, kemudian akan menampilkan informasi melalui LCD $16 \times 2$. Sedangkan perancangang hardware menggunakan sensor Altimeter sebagai alat pengukur ketinggian dataran tinggi secara otomatis.

\subsection{Perakitan Alat Pengukur Ketinggian}

Proses Perakitan alat pengukur tinggi Plateau untuk memenuhui pengendalian objek dapat dilihat pada Gambar 9.

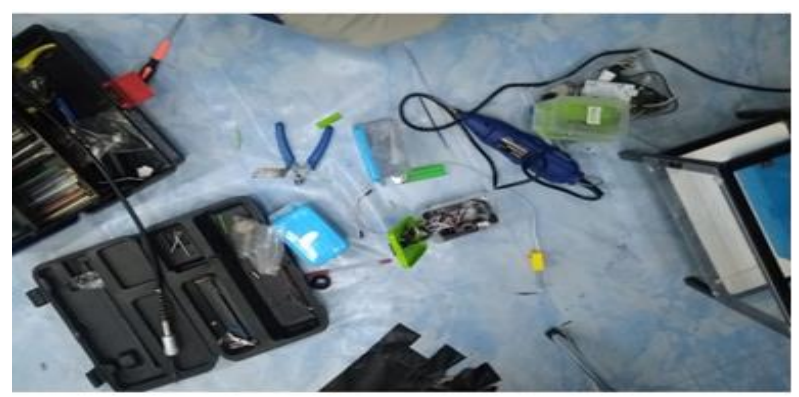

\section{Gambar 8. Proses Perakitan Alat Pengukur Ketinggian Plateau}

\subsection{Instalasi Perangkat Alat}

Instalasi perangkat keras merupakan suatu proses instalasi alat ataupun perakitan alat yang digunakan dalam membangun adalah Sensor Altimeter untuk mengukur ketinggian dari dataran titik 0 laut sampai ke dataran tinggi berbasis Atmega 328. Adapun Instalasi perangkat alat pengukur ketinggian plateau dapat dilihat pada gambar 10 .

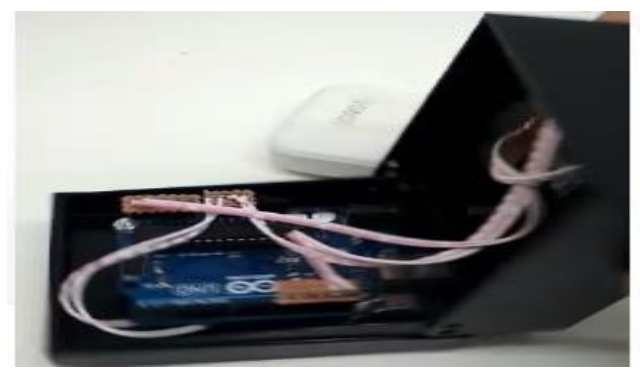

\section{Gambar 9. Instalasi Perangkat Alat Pengukur Ketingian Plateau}

\subsection{Tampilan Awal LCD}

Tampilan awal digital sebagai pengendali utama dalam pengiriman teks pada $L C D$ display, dimana teks yang dikirim akan ditampilkan pada Modul LCD. Sebelum pengiriman pastikan port sudah terdeteksi. Adapun hasil dari perakitan alat pengukur ketinggian, perangkat keras yang digunakan untuk memenuhui pengendalian objek dapat dilihat pada gambar 11 .

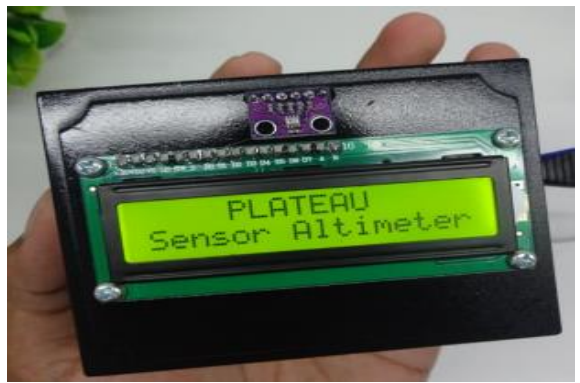

Gambar 10. Tampilan Awal LCD alat pengukur ketingian Plateau.

\subsection{Tampilan Ketinggian Dan Suhu}

Dengan memanfaatkan tekanan udara berdasar ketinggian terhadap permukaan laut, maka sensor ini juga dapat mengukur ketinggian (Altimeter). Sensor akan secara otomatis mendeteksi ketinggian. Hasil dari pengukuran akan ditampilkan melalui LCD display, dapat dilihat pada Gambar 12.

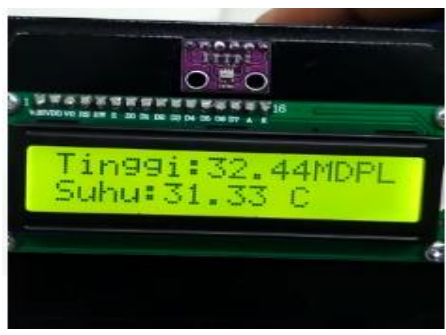

Gambar 11. Tampilan Ketinggian Dan Suhu alat pengukur ketingian Plateau 
Untuk menemukan apakah perangkat lunak sudah berjalan sesuai dengan semestinya, tidak memiliki masalah eror dan sesuai apa yang diharapkan. Pengujian mengunakan Metode BlackBox dalam penelitan ini menggunakan teknik sensor altimeter untuk mengukur ketinggian dari permukaan titik 0 laut sampai ke dataran tinggi akan menjalankan proses yang tepat dan menghasilkan output sesuai dengan rancangan. Metode ini digunakan untuk mengetahui apakah perangkat lunak berfungsi dengan benar, pengujian sensor altimeter merupakan perancangan data uji yang di dasarkan pada sepesifikasi perangkat lunak yang dibuat dapat dilihat pada tabel 2 .

Tabel 1 adalah Pengujian Perangkat Lunak.

\begin{tabular}{|l|c|l|l|}
\hline \multicolumn{1}{|c|}{$\begin{array}{c}\text { Input } \\
\text { Pengujian }\end{array}$} & $\begin{array}{l}\text { Fungsi } \\
\text { Sensor }\end{array}$ & $\begin{array}{l}\text { Hasil Yang } \\
\text { Diharapkan }\end{array}$ & Hasil Uji \\
\hline $\begin{array}{l}\text { Melakukan } \\
\text { pengujian } \\
\text { sensor }\end{array}$ & Aktif & $\begin{array}{l}\text { Sensor } \\
\text { mendekteksi } \\
\text { LCD menyala }\end{array}$ & $\begin{array}{l}\text { Memenuhi } \\
\text { / Ok }\end{array}$ \\
\hline $\begin{array}{l}\text { Melakukan } \\
\text { pengujian } \\
\text { LCD }\end{array}$ & Aktif & $\begin{array}{l}\text { Diharapkan } \\
\text { LCD aktif } \\
\text { dengan } \\
\text { memunculkan } \\
\text { suatu tulisan } \\
\text { dan huruf }\end{array}$ & $\begin{array}{l}\text { Memenuhi } \\
\text { / Ok }\end{array}$ \\
\hline $\begin{array}{l}\text { Melakukan } \\
\text { pengujian } \\
\text { Keakuratan } \\
\text { Suhu }\end{array}$ & Aktif & $\begin{array}{l}\text { Diharapkan } \\
\text { sensor } \\
\text { mendeteksi }\end{array}$ & $\begin{array}{l}\text { Memenuhi } \\
\text { / Ok }\end{array}$ \\
\hline $\begin{array}{l}\text { Melakukan } \\
\text { pengujian } \\
\text { Keakuratan } \\
\text { Ketinggian }\end{array}$ & Aktif & $\begin{array}{l}\text { Diharapkan } \\
\text { sensor } \\
\text { mendeteksi } \\
\text { ketinggian }\end{array}$ & Memenuhi \\
/ Ok
\end{tabular}

Data hasil pengujian yang telah dilakukan terhadap kinerja Alat tersebut menunjukkan bahwa Alat dapat bekerja dengan baik, mudah digunakan dan lebih efisien karena Alat ini hanya membutuhkan baterai atau power bank untuk menampilkan di layar LCD dan mempermudah proses pengukuran ketinggian dan temperature di dataran tinggi sehingga di harapkan dapat membantu pendaki dan masyarakat umum dalam mengukur ketinggian dataran tinggi ( PLATEAU ).

\section{KESIMPULAN}

Kesimpulan dari penelitian ini adalah membuat alat sensor Altimeter lebih praktis untuk mengukur dataran tinggi dari titik nol laut sampai ke dataran tinggi menggunakan sensor altimeter dan aplikasi platium $\mathrm{C}$ Arduino IDE dengan cara kerja otomatis dan adanya sensor Altimeter dengan berbasis ATMega328 ini semua orang dapat mengukur ketinggian di dataran tinggi tanpa ada kendala jaringan karena ATMega328 dirancang secara khusus tanpa mengandalkan bantuan jaringan atau internet.

\section{SARAN}

Berdasarkan hasil penelitian pembuatan alat masih terdapat kekurangan untuk pengembangan berikutnya alangkah baiknya sistem dirancang agar dapat mengolah dan menyimpan data dalam sistem secara otomatis berupa grafik, file atau database., maka diharapkan kepada penelitian berikutnya untuk bisa menggembangkan penelitian ini jauh lebih baik.

\section{DAFTAR PUSTAKA}

Alfred Tenggono, Yovan Wijaya Kusuma, W. (2015) 'Sistem Monitoring Dan Peringatan Ketinggian Air Berbasis Web Dan SMS Gateway', 5(2), pp. 119-129.

Amelius Andi Mansawan (2017) 'Potensi Data Satelit Altimeter Untuk Pengukuran Tinggi Paras Laut Di Daerah Pantai Cilacap Dan Benoa'.

Dari, W. (2015) 'Penerapan Metode System Development Life Cycle Pada Pembuatan Sistem Informasi Penjualan Produk Batik Kurowo Jakarta', 3(2), pp. 222-228.

Djuandi, F. (2011) 'Pengenalan arduino', pp. 1-24.

Girsang, I. S. and Perangin-angin, B. (2012) 'Perancangan Monitoring Jarak Jauh Ketinggian Air Pada Bendungan Menggunakan Sistem Android Via Jaringan Wi-Fi', pp. 1-7.

Hadinegara, F. (2018) 'Perancangan Alat Ukur Massa Jenis Udara Menggunakan Sensor BMP280 dan DHT280 berbasis arduino'.

M. Syafik Mukhlis, Yamato, A. R. M. (2015) 'Sistem Mikrokontroler Atmega328 sebagai Pengontrol Suhu Dan Level Air', (Lcd), pp. 1-10.

Meivita, D. N. (2016) 'Rancang Bangun Alat Ukur Kondisi Kesehatan Pada Pendaki Gunung Berbasis Fuzzy Logic', pp. 13-18.

Restanti, B. (2012) 'Prototype Instrumen Alat Ukur Untuk Kondisi Pada Pendaki Gunung'.

Zuly Budiarso, E. N. (2011) 'Sistem Monitoring Tingkat Ketinggian Air Bendungan Bebasis Mikrokontroller'.

\section{UCAPAN TERIMA KASIH}

Penulis mengucapkan terimakasih kepada Direktur Politeknik Harapan Bersama Tegal, Ketua Pusat Penelitian dan Pengabdian Masyarakat Politeknik Harapan Bersama Tegal, Program Studi DIII Teknik Komputer Politeknik Harapan Bersama Tegal, Kepala Bappeda, Kepala BPBD Kabupaten Tegal serta Rekanrekan Dosen dan Staf Program Studi DIII Teknik Komputer yang telah membantu memberikan saran dalam pembutan laporan ini. 